\title{
Determination of Effect of Nitrogen Fertilization on Some Quality Properties of Salep Orchid (Orchis sancta L.) Cultivated in Field Conditions in Turkey
}

\author{
Olcay ARABACI ${ }^{1}$, Uğur TAN* ${ }^{1}$, Özge YILDIZ², Mehmet TUTAR ${ }^{2}$ \\ ${ }^{1}$ Adnan Menderes University, Faculty of Agriculture, Field Crops, 09100 Aydın, Turkey \\ ${ }^{2}$ Aegean Agricultural Research Institute, Menemen-Izmir, Turkey
}

Received: 04 May 2017 - Revised: 18 June 2017 - Accepted: 03 September 2017

\begin{abstract}
Turkey has rich biodiversity due to located at the intersection of Europe-Siberia, Mediterranean and Iran-Turan flora regions. Orchidaceae family has a distinct place within this rich biodiversity. It has been reported total 204 orchid species those belongs to the 24 genera are grown in Turkey. The exports of the salep orchids were banned in 1974 by the Ministry of Agriculture due to high destruction of natural distribution areas of the plant. Despite the fact that nowadays the salep plants are protected by laws, the tubers of salep orchids still have been collected by people. Washing, boiling in water or milk, washing in cold water and drying stages are used to prevent growing activity of salep tubers. After this, tubers of salep are grind and prepared to use as salep powder. All of salep production is provided by collection of salep tubers from nature. For one kilogram of salep, 1000-4000 tubers is used. And it was assumed that our country produces 45 tons of tubers per year.This study was carried out to determine the effect of nitrogen fertilization on some quality characteristics of Orchis sancta L. grown in field conditions, in order to take part in agricultural cultivation of salep orchids. In the study, the effect of four fertilizer doses $(0,5,10$ and $15 \mathrm{~kg} / \mathrm{da})$ was investigated on starch ratio $(\%)$, mucilage ratio $(\%)$, protein ratio $(\%)$ and ash ratio (\%). Mucilage ratio (salep mannia) was varied between $14 \%$ and $26 \%$ according to nitrogen fertilizer doses.
\end{abstract}

Keywords: Salep, Orchis sancta L., Cultivation, Nitrogen fertilizer, Quality.

\section{INTRODUCTION}

Turkey has rich biodiversity due to located at the intersection of Europe-Siberia, Mediterranean and Iran-Turan flora regions. Orchidaceae family has a distinct place within this rich biodiversity. It has been reported total 204 orchid species those belongs to the 24 genera are grown in Turkey. Forty-nine of these 204 species were hybrid species. Seventeen species of Turkish orchids contain tubers. Excludes six of them (Coeologlossum, Gymnadenia, Listera, Spiranthes, Steveniella, Traunsteinera), others (Aceras, Anacamptis, Barlia, Comperia, Dactylorhiza, Himantoglossum, Neotinea, Ophrys, Orchis, Platanthera, Serapias) are benefited from the use of salep [1-3]. Salep has been obtained as a result of the natural collection of tubers of Orchidaceae family. Many endemic orchid species have been collected from nature for many years and now they are almost about to extinction [4].

\footnotetext{
*Corresponding Author E-mail: ugur.tan@adu.edu.tr
} 
The exports of the salep orchids were banned in 1974 by the Ministry of Agriculture due to high destruction of natural distribution areas of the plant [5]. Despite the fact that nowadays the salep plants are protected by laws, the tubers of salep orchids still have been collected by people. Washing, boiling in water or milk, washing in cold water and drying stages are used to prevent growing activity of salep tubers. After this, tubers of salep are grinded and prepared to use as salep powder. salep powder has starch, sugar, mucilage and nitrogenous compounds in its composition. salep is a plant-derived polysaccharide, contain 7-6\% glucomannan, 8-19\% starch, $0.5-1.5 \%$ nitrogenous substances, $0.2-6 \%$ ash (dry matter), 1-4\% sugar and 6-12\% moisture [6-8].

salep is put in the final product as flavor purpose [9]. The salep has darkening effect when added any formulation so it does increase viscosity that provides higher product quality, also glucomannan provides stabilization for ice cream. Salep provides unique structural taste and aroma to Maraş-type ice cream [10,11]. Salep drinks that consumed fondly in the winter are prepared in two ways, with milk or plain. According to the conventional method, salep powder and starch are put together in water or milk, and it is boiled by mixing slowly. When it gets thick, it is cooked little more by putting sugar into it [12]. All of salep production is provided by collection of salep tubers from nature. For one kilogram of salep, 1000-4000 tubers is used. And it was assumed that our country produces 45 tons of tubers for per year $[13,14]$.

Cultivation of highly demanding plants are necessary for conservation and sustainable of natural resources. Orchis sancta L. is one of the most commonly collected species from nature in the Aegean Region. This study was carried out to determine the effect of nitrogen fertilization on some quality characteristics of Orchis sancta L. grown in field conditions, in order to take part in agricultural cultivation of salep orchids.

\section{MATERIAL and METHODS}

Orchis sancta L. is a perennial plant that called locally pürin flower or piriç flower. It is a non-endemic species of Eastern Mediterranean that spreads in grassland and calcareous soil between $0-450 \mathrm{~m}$ altitudes in Western and Southern Anatolia. It is also located in Greece, Aegean, Cyprus and Western Syria [15]. The experiment material of this study is Orchis sancta L. seedlings that taken from another research that conducted at Aegean Agricultural Research Institute. This study was carried out during the period of 2012-2014 in Adnan Menderes University (ADU), Faculty of Agriculture Research, Application and Production field.

The province of Aydin where the experiment was conducted resides in the Mediterranean region and it was under the influence of temperate Mediterranean climate. Due to the Mediterranean climate, the plants in the country are beginning to grow in late winter and early spring.

In this study, commercial nitrogen fertilizer with 4 different doses $(0,5,10,15 \mathrm{~kg} / \mathrm{da})$ was conducted in three replications according to randomized blocks trial design. The seedlings of Orchis sancta L. were planted to $1 \mathrm{~m}$ width and $25 \mathrm{~cm}$ height planting sites with $20 \times 20 \mathrm{~cm}$ distance in first year 21/12/2012 and second-year 30/11/2013. Thirty-six seedlings were used for each parcel and total 432 seedlings were used in the experiment. Half of the nitrogen fertilizer doses and $10 \mathrm{~kg} / \mathrm{da}$ raw $\mathrm{P}$ and $\mathrm{K}$ fertilizer were given as basic fertilizer before planting. Other half of the nitrogen fertilizer doses in the study was used during the rosette period of the plants.

The removal of weeds was made with the hoe when it is necessary during the growth of the plants. Plants have benefited from rainfall due to good rainfall during the vegetation process so there was not needed for irrigation. The harvest was carried out on 17/05/2013 of the first year and on 07/05/2014 of the second year. Quality analyses were carried out in Aegean Agricultural Research Institute Technology Laboratory. Preliminary preparations before the 
analysis were carried out at the Medical Plants Laboratory of the Field Crops Department of ADU Agriculture Faculty. In the study, the effects of four fertilizer doses $(0,5,10$ and $15 \mathrm{~kg} / \mathrm{da})$ on the starch ratio $(\%)$, mucilage ratio $(\%)$, protein ratio $(\%)$ and ash ratio $(\%)$ were investigated.

Starch ratio (\%): It was performed enzymatically and spectrophotometrically according to Amyloglucosidase/alfa amylase method (AOAC METHOD 996.11, AACC METHOD 7613.01) [16].

Mucilage ratio (\%): Samples were weighed for 1'g and placed in a $25 \mathrm{ml}$ graduated cylinders. The samples in the graduated cylinders were soaked with $1 \mathrm{ml}$ of $96 \%$ ethanol and completed to $25 \mathrm{ml}$ with purified water. The samples were shaken every 1-hour intervals for 10 minutes and this process was repeated for 3 times [17].

Protein ratio (\%): It was carried out by DUMAS method [18]

Ash ratio (\%): $1 \mathrm{~g}$ of the sample was placed in porcelain crucibles and were weighed, then the porcelain crucibles were burnt in an ash oven at $600{ }^{\circ} \mathrm{C}$. The samples were weighed again and the ash amounts were determined [17].

Due to a high number of quality analyses, trial replications were combined and analyses were carried out in parallel. For this reason, the data have not subjected to statistical analysis and were interpreted in a table form for information purposes..

\section{RESULTS}

A two-year study of nitrogen fertilizer and quality measures of Orchid sancta L. was given in Table 1. The effect of nitrogen fertilizer on the starch ratio was determined in the experiment. It was observed that the values changed between 12.946-24.822\% in the first year and between 17.229-28.391\% in the second year. The biennial mean values varied between $17.134-25.099 \%$ and the highest value was obtained at $5 \mathrm{~kg} / \mathrm{da}$ nitrogen application (Table 1, Figure 1.).

Table 1. Effects of nitrogen fertilizer on some quality characteristics of Orchis sancta L.

\begin{tabular}{ccccccc}
\hline \multirow{2}{*}{ Nitrogen Fertilization } & \multicolumn{3}{c}{ Starch Ratio (\%) } & \multicolumn{3}{c}{ Mucilage Ratio (\%) } \\
& 1. Year & 2. Year & Mean & 1. Year & 2. Year & Mean \\
\hline $0 \mathrm{~kg} / \mathrm{da}$ & 16.965 & 17.303 & 17.134 & 22.000 & 26.000 & 24.000 \\
$5 \mathrm{~kg} / \mathrm{da}$ & 21.807 & 28.391 & 25.099 & 14.000 & 18.000 & 16.000 \\
$10 \mathrm{~kg} / \mathrm{da}$ & 24.822 & 17.229 & 21.025 & 18.000 & 25.000 & 21.500 \\
$15 \mathrm{~kg} / \mathrm{da}$ & 12.946 & 21.347 & 17.146 & 19.000 & 23.000 & 21.000 \\
Mean & 19.135 & 21.068 & 20.101 & 18.300 & 23.000 & 19.600 \\
\hline \multirow{3}{*}{ Protein Ratio $(\%)$} & \multicolumn{3}{c}{ Ash Ratio $(\%)$} \\
\hline Nitrogen Fertilization & 1. Year & 2. Year & Mean & 1. Year & 2. Year & Mean \\
\hline $0 \mathrm{~kg} / \mathrm{da}$ & 11.892 & 14.568 & 13.230 & 19.95 & 8.04 & 13.99 \\
$5 \mathrm{~kg} / \mathrm{da}$ & 10.371 & 13.737 & 12.054 & 16.18 & 6.60 & 11.39 \\
$10 \mathrm{~kg} / \mathrm{da}$ & 11.966 & 14.885 & 13.426 & 19.78 & 7.12 & 13.45 \\
$15 \mathrm{~kg} / \mathrm{da}$ & 14.991 & 10.323 & 12.657 & 13.86 & 5.77 & 9.82 \\
Mean & 12.305 & 13.378 & 12.842 & 17.44 & 6.88 & 12.16 \\
\hline
\end{tabular}



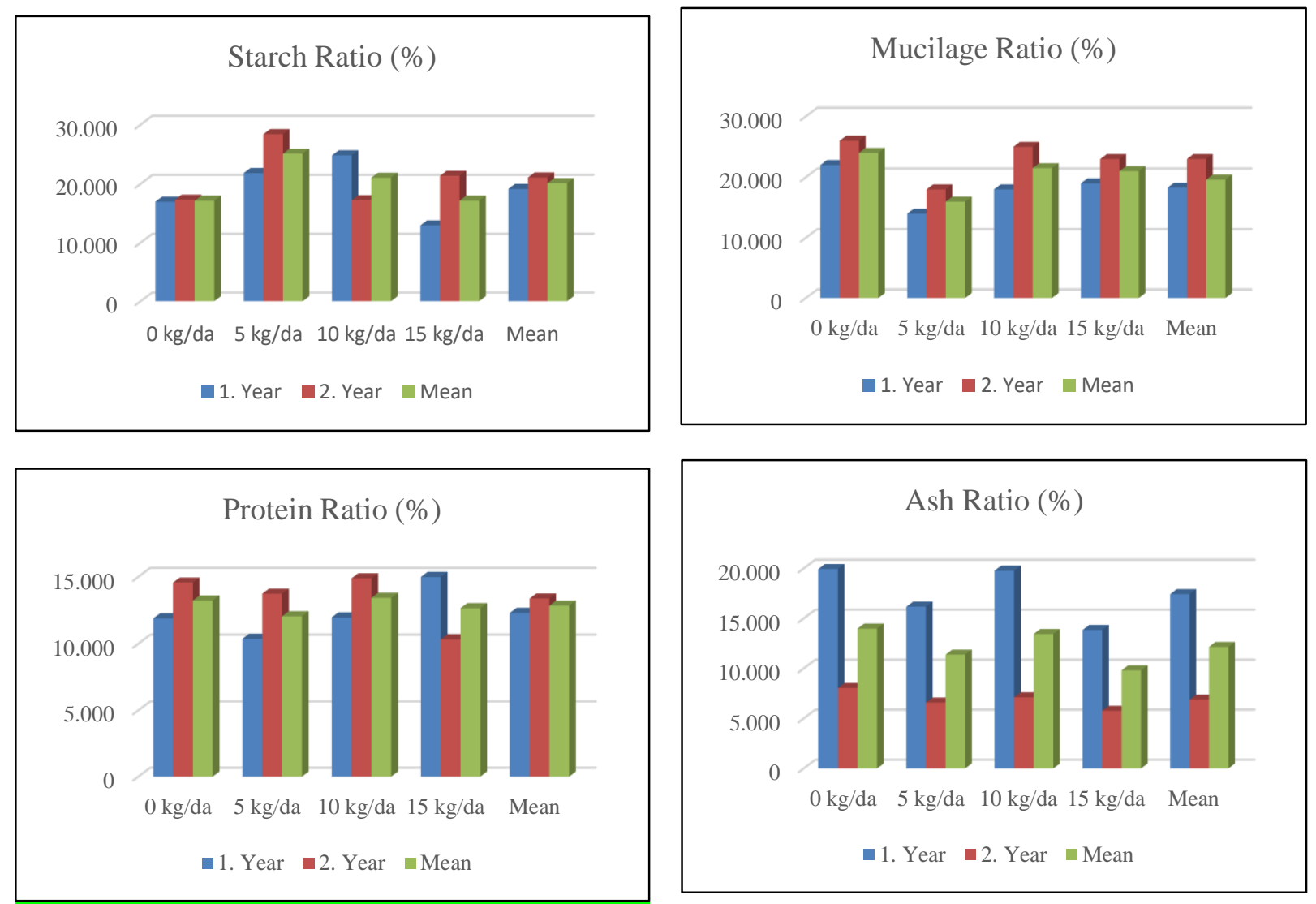

Figure 1. Effects of nitrogen fertilizer on starch, mucilage, protein and ash ratio of Orchis sancta L.

It was determined that the protein ratio was changed according to doses of nitrogen in the experiment. Protein ratio was varied between 10.371-14.991\% in the first year, 10.323$14.885 \%$ in the second year and $12.054-13.426 \%$ for a mean of both years. According to the results of two years, the highest protein value was reached $13.426 \%$ at $10 \mathrm{~kg} / \mathrm{da}$ nitrogen application (Table 1., Figure 1.).

The ash ratio was found $17.44 \%$ in the first year, $6.88 \%$ in the second year and $12.16 \%$ in mean of both years. According to mean of both years, control has the highest value of ash ratio that $13.99 \%$, it was followed by $10 \mathrm{~kg} / \mathrm{da}$ nitrogen application with $13.45 \%$ (Table 1 , Figure 1).

\section{DISCUSSION}

According to study that was carried out in 1865 by Dragendorf indicates that salep contains $48 \%$ mucilage, $27 \%$ starch, $5 \%$ protein, $2 \%$ ash and $1 \%$ oz (sugar) [19]. It was reported that there were differences in chemical content of salep orchids depending on different species [7]. It has been determined that mucilage ratio of different genus and species collected from Muğla region was varied between $6.82-61.05 \%$, starch ratio $0.45-36.04 \%$, total nitrogen ratio $0.57-0.95 \%$ and ash ratio $0.27-5.98 \%$ [6]. In the same study, the researcher determined that mucilage ratio and starch ratio of Orchis sancta L. was $15.70 \%$ and $10.64 \%$ respectively [6].

It was determined that commercial Maraş salep has $55.17 \%$ glucomannan and $2.70 \%$ starch content [20]. It was also reported that salep should contain $>40 \%$ of glucomannan and $<8 \%$ of starch for production of Maras-type ice cream. It was reported that the salep contents (mucilage, starch, reducing sugar, non-reducing sugar, total nitrogen, water and ash ratios) were 
changed between $(6-61 \%),(0.6-36 \%),(0.4-4.5 \%),(0,1-2,3 \%),(0.4-1.2 \%),(6-12 \%)$ and $(0.2-$ $9 \%)$ respectively [21].

Our study aim for cultivation, it is very important because the previous studies do not contain cultivation knowledge and they only give general information about their region that they work. When we compare the values obtained by Sezik (1967) with our values in Orchis sancta L., it was determined that the mucilage and starch ratios in our study were higher than researcher's findings [6]. On the other hand, another study's mucilage value was higher than our finding and our starch value was higher than their finding [17]. Our mucilage and starch findings were similar with Akgül (1993) however protein and ash values higher than his values [18].

\section{CONCLUSION}

The effect of nitrogen fertilization on some quality characteristics of Orchis sancta L. was determined in Aydin ecological conditions. Nitrogen fertilizer applications have a positive effect on the starch and protein ratios of Orchis sancta L. and have a negative effect on the mucilage ratio. The starch ratio and protein ratio was determined between 17.134-25.099\% and $12.054-13.426 \%$ respectively. The highest values were obtained with $5 \mathrm{~kg} / \mathrm{da}$ and $10 \mathrm{~kg} / \mathrm{da}$ nitrogen applications, respectively. On the other hand, the mucilage ratio was determined between 16-24\% and the highest values obtained from control application. In the same experiment, the ash content was found in the range of 9.82-13.99\% and the lowest values were determined with $15 \mathrm{~kg} / \mathrm{da}$ nitrogen application.

This study was a unique study due to the first study in the field conditions for salep. The results are promising for the growth of salep orchids in field conditions. $5 \mathrm{~kg} / \mathrm{da}$ nitrogen fertilization can recommend for starch ratio, $0 \mathrm{~kg} / \mathrm{da}$ for mucilage ratio, $10 \mathrm{~kg} / \mathrm{da}$ for protein and $15 \mathrm{~kg} / \mathrm{da}$ for ash ratio. Due to mucilage ratio is used as darkening for maras-type icecream, $0 \mathrm{~kg} / \mathrm{da}$ nitrogen fertilization recommended for cultivation of Orchis sancta L.

\section{Acknowledgement}

This study was supported by The Scientific Research Projects Coordination Department in Adnan Menderes University, Project No: ZRF-13003.

\section{Conflict of Interests}

Authors declare that there is no conflict of interests.

\section{REFERENCES}

[1] Sezik, E., (1984). Orkidelerimiz (Türkiye'nin Orkideleri), Sandoz Kültür Yayınları No.6, 166.

[2] Sezik, E., İşler, N., Güler, N., Orhan, Ç., Aybeke, M., Deniz, İ.G., \& Üstün, O., (2007). Salep ve Orkidelerin Tarribi, Tübitak, TBAG-Ç.SEK/23(103T008), Sonuç Raporu, Ankara.

[3] Sezik, E., (2012). Salep mi? Orkideler mi? Türkiye 2. Orkide ve Salep Çalıştayı, 25-26 Nisan 2012, İzmir, pp. 37-44.

[4] Özhatay, N., Koyuncu, M., Atay, S., \& Byfield, A., (1997). Türkiye'nin Doğal Tibbi Bitkilerinin Ticareti Hakkında Bir Çalışma, Doğal Hayatı Koruma Derneği, İstanbul.

[5] Baytop, T., (1999). Türkiye'de Bitkiler ile Tedavi, I. Ü. Ecz. Fak. Yayın No: 325540/40 İstanbul pp. 326-327. 
[6] Sezik, E., (1967). Türkiye'nin Salepgilleri Ticari Salep Çeşitleri ve Özellikle Muğla Salebi Üzerinde Araştırmalar. Doktora Tezi, İstanbul Üniversitesi, Eczacılık Fakültesi Farmakognozi Kürsüsü, İstanbul.

[7] Baytop, T., \& Sezik, E., (1968). Türk Salep Çeşitleri Üzerinde Araştırmalar. Journal of the Faculty of Pharmacology 4: 61-68. doi: 10.1501/ Eczfak

[8] Tekinşen, K.K., \& Güner, A., (2009). Kahramanmaraş Yöresinde Yetişen Saleplerin Kimyasal Bileşiminin ve Bazı Fizikokimyasal Niteliklerinin Araştırılması, S.Ü. BAP Proje No: 06401061, Konya.

[9] Kaya, S., \& Tekin, A.R., (2001). The Effect of Salep Content on The Rheological Characteristics of A Typical Ice-Cream Mix. Journal of Food Engineering 47: 59-62.

[10] Ayar, A., Sert, D., \& Akbulut, M., (2009). Effect of salep as a hydrocolloid on storage stability of 'Íncir Uyutmas1' dessert. Food Hydrocolloids, 23(1), 62-71. doi: 10.1016/j.foodhyd.2007.11.014

[11] Kayacier, A., \& Dogan, M., (2006). Rheological Properties of Some Gums-Salep Mixed Solutions. Journal of Food Engineering, 72(3), 261-265.

[12] Anonim (2011) Retrieved from:http://www.lokmanhekimimiz.com/1149/Urunlerimiz/Sifali-Bitkiler/Salep-HakikiSaf-Salep-SAHLEP-50-GR.aspx

[13] Erdem, H. E. (2004). Biyolojik çeşitliliğin Ekonomik Değerinin Belirlenmesi: Yabani Orkide Örneği. Ege Üniv. Fen Bilimleri Enst. (Master thesis). Çevre Bilimleri Ana Bilim Dalı. Bornova-İzmir pp.99.

[14] Sandal Erzurumlu, G., \& Doran, İ., (2011). Türkiye'de Salep Orkideleri ve Salep Kültürü, HR. Ü.Z.F. Dergisi, 15(1): 29-34.

[15] Tubives, 2016. Retrieved from: http://www.tubives.com /index.php?sayfa=1\&tax_id=9577

[16] McCleary, B. V., \& Monaghan, D. A., (2002). Measurement of Resistant Starch. J. AOAC Int., 85, pp.665-675.

[17] Kaya, N., (1998). Biyokimya Uygulama K1lavuzu. E.Ü. Zir. Fak. Yayın. Ders Notları 57/1.

[18] Anonymous (1976). American Association of Cereal Chemists: "Approved Methods of the AACC" Method 76-11.

[19] Sezik, E., Özer, B., (1983). Kastamonu Salebinin Menşei ve Kastamonu Civarının Orkideleri. TÜBİTAK Proje No: TBAG -424, Ankara.

[20] Tekinşen, O.C., \& Karacabey, A., (1984). Bazı Stabilizatör Karışımlarının Kahramanmaraş Tipi Dondurmanın Fiziksel ve Organoleptik Nitelikleri Üzerine Etkisi, TÜBITAK Proje No: VHAG 594, Ankara.

[21] Akgül, A., (1993). Baharat Bilimi ve Teknolojisi. Gıda Teknolojisi Derneği Yayınları, Ankara pp.142-143. 